4

\title{
Combined oxygen and sulphur isotope analysis-a new tool to unravel vertebrate (paleo)-ecology
}

\author{
Jean Goedert ${ }^{1} \cdot$ Romain Amiot $^{1} \cdot$ Didier Berthet $^{2} \cdot$ François Fourel $^{3} \cdot$ Laurent Simon $^{3} \cdot$ Christophe Lécuyer $^{1,4}$ \\ Received: 3 October 2019 / Revised: 13 December 2019 / Accepted: 19 December 2019 \\ (C) Springer-Verlag GmbH Germany, part of Springer Nature 2019
}

\begin{abstract}
Reconstructing the living environment of extinct vertebrates is often challenging due to the lack of proxies. We propose a new proxy to the living environment based on the combined oxygen and sulphur stable isotope analysis of vertebrate hydroxyapatite. We tested this isotopic proxy to 64 biogenic apatite (bones) samples that represent a wide spectrum of the extant vertebrate phylogenetic diversity including crocodiles, snakes, turtles, mammals, birds, lizards, fish and amphibians. We show that the combination of these two isotopic systems allows the living environment of all these vertebrates to be unambiguously distinguished between freshwater (aquatic vs semi-aquatic), seawater (aquatic vs semi-aquatic) and terrestrial. The main goal of this study is to provide a present-day isotopic reference frame and to discuss methodological issues that will serve to interpret future oxygen and sulphur isotope results obtained either from fossil or modern skeletal material. This new isotopic approach of combined oxygen and sulphur isotope analysis will be particularly useful to document major aquatic-terrestrial transitions in the fossil record but also to better constrain the living environment of some present-day species.
\end{abstract}

Keywords Geochemistry $\cdot$ Stable isotope $\cdot$ Biogenic apatite $\cdot$ Ecology $\cdot$ Fossil

\section{Introduction}

\section{Background information}

Vertebrate evolution has been many times punctuated by ecological transitions between terrestrial and aquatic (freshwater vs seawater) environments resulting in major radiation events: during the Late Devonian-Early Carboniferous, early tetrapods left

Communicated by: Aurora Grandal-d'Anglade

Electronic supplementary material The online version of this article (https://doi.org/10.1007/s00114-019-1664-3) contains supplementary material, which is available to authorized users.

Jean Goedert

jean.goedert@protonmail.fr

Christophe Lécuyer

christophe.lecuyer@univ-lyon1.fr

Romain Amiot

romain.amiot@univ-lyon1.fr

Didier Berthet

didier.berthet@museedesconfluences.fr

François Fourel

francois.fourel@univ-lyon1.fr aquatic environments and colonised terrestrial ones (Ahlberg and Milner 1994); during the Jurassic-Cretaceous, various crocodylomorphs belonging to the thalattosuchians, the pholidosaurids, the dyrosaurids and the eusuchians, radiated in the marine environments (Martin et al. 2014); One hundred million years later, during the Cenozoic (Eocene), early cetaceans also experienced a secondary adaptation to aquatic environments (Gingerich et al. 2001). Reconstruction of a thorough picture of
Laurent Simon

laurent.simon@unvi-lyon1.fr

1 CNRS, UMR 5276 LGL-TPE, Univ Lyon, Université Lyon 1, Ens de Lyon, 69622 Villeurbanne, France

2 Musée des Confluence de Lyon, Lyon, France

UMR 5023 LEHNA, ENTPE, Université de Lyon, CNRS, Université Claude Bernard Lyon 1, F-69622 Villeurbanne, France

4 Institut Universitaire de France, Paris, France 
these ecological transitions requires detailed knowledge of the living environment of the extinct taxa involved.

Terrestrial, freshwater and marine environments have different physical and chemical properties such as density, viscosity and salinity, resulting in specific morphological and physiological adaptations of living species. Consequently, the morphofunctional analysis of skeletal remains of fossil taxa has often been used to elucidate their living environment. (Coates and Clack 1990; Fernández and Gasparini 2000; Pierce et al. 2012; Spoor et al. 2002). However, skeletal remains sometimes may be incomplete or may have lost their original shape during postdepositional events such as burial and tectonic deformation or compaction. Such processes preclude a reliable interpretation of anatomical features in terms of morpho-functionality. Furthermore, soft tissues indicative of specific environments such as salt glands are easily degraded, and delicate ossified structures such as the semicircular canal system of the inner ear are rarely preserved in the fossil record. Finally, morphological features can predate functional adaptation (exaptation process) so that it can be misinterpreted in terms of living environment.

The sediments in which vertebrate fossils are embedded also constitute an important source of information. The detailed study of the lithology, petrology and geochemistry, along with sedimentary structures, allows precise reconstruction of the environmental conditions that prevailed during the deposition of the sediments. However, the living environment of vertebrates does not necessarily represent the depositional environment in which they were embedded (e.g. anoxic bottom waters). This is particularly true for vertebrates that travel long distances or migrate (e.g. anadromous and catadromous fish). Furthermore, carcasses can be transported over long distances after death resulting in a mismatch between the environment deduced from the sediment of the taphocoenosis and the genuine living environment.

Those problems have raised the need for other methods to reconstruct living environments independently of vertebrate morphology and depositional environments. For instance, stable carbon, oxygen or strontium isotope compositions of bones and teeth have been used as direct tracers of the living environment and applied to fossilised remains, such as those of early tetrapods (Goedert et al. 2018), early cetacean (Roe et al. 1998; Clementz et al. 2006) or crocodilian taxa (Martin et al. 2016), to get a better picture of these major ecological transitions. Here, we propose a new method to determine past living environments of vertebrates based on the combined analysis of oxygen and sulphur isotope compositions of their biogenic apatite.

\section{Oxygen isotope composition of vertebrate apatite}

Oxygen isotope composition of surface waters $\left(\delta^{18} \mathrm{O}_{\mathrm{w}}\right)$ is mainly controlled by evaporation and condensation processes during which isotopic fractionation takes place (Craig and Gordon 1965; Dansgaard 1964). Marine environments have relatively uniform $\delta^{18} \mathrm{O}_{\mathrm{w}}$ values of $0 \pm 1 \%$ except at high latitudes, where $\delta^{18} \mathrm{O}_{\mathrm{w}}$ values are lower, ranging from -3 to $-1 \%$ due to mixing with ice melt, and at tropical latitudes where high evaporation rates result in positive $\delta^{18} \mathrm{O}_{\mathrm{w}}$ values ranging from +1 to $+2 \%$, especially in closed tropical and subtropical seas like the Red Sea, the Dead Sea, Mediterranean Sea or Caribbean Sea (Craig and Gordon 1965; Gat 1984; Gat et al. 1996). Hypersaline lagoons or sabkhas (but also inland lakes, e.g. in East Africa) can also reach $\delta^{18} \mathrm{O}_{\mathrm{w}}$ values higher than $+2 \%$ (e.g., Gat and Levy 1978).

The $\delta^{18} \mathrm{O}_{\mathrm{w}}$ values of freshwaters mainly derive from those of meteoric waters (groundwater contributions being possible) whose ultimate source is seawater. Evaporation of seawater at low latitudes, distillation and cooling of the humid air mass during its transport towards high latitudes are responsible for the negative $\delta^{18} \mathrm{O}$ values of meteoric waters (Dansgaard 1964). At the global scale, the higher the latitude and altitude, the lower the $\delta^{18} \mathrm{O}$ values of rainfall and snow. These values are comprised between -6 and $-2 \%$ at low latitudes and decrease down to about $-15 \%$ at high latitudes, polar caps excluded. Oxygen isotope compositions of vertebrate biogenic apatite phosphate $\left(\delta^{18} \mathrm{O}_{\mathrm{p}}\right)$ are linearly correlated with the oxygen isotope composition of their environmental waters (Longinelli 1984; Luz et al. 1984). Consequently, vertebrates living or ingesting different environmental waters will record in their bones distinct oxygen isotope compositions. Nonetheless, it is worth to note that physiological factors such as evaporative transcutaneous water loss and thermo-metabolism, which are species-specific, also impact the oxygen isotope compositions recorded in bioapatites (e.g. Kohn 1996; Levin et al. 2006).

\section{Sulphur isotope composition of vertebrate apatite}

Sulphur isotope composition of sulphates $\left(\delta^{34} \mathrm{~S}\right)$ is highly variable in modern aquatic environments. Marine environments have high and relatively uniform sulphate $\delta^{34} \mathrm{~S}$ values close to + 21.0\% (Böttcher et al. 2007). Most freshwater environments (e.g. rivers, lakes, ponds, precipitations) have comparatively lower sulphate $\delta^{34} \mathrm{~S}$ values, ranging from -20.0 to $+20.0 \%$ (Krouse 1980; Kaplan 1983; Nehlich 2015). It has been shown that the sulphur isotope composition of food is recorded in vertebrate organic tissues (e.g. muscles, hairs) or molecules (e.g. bone collagen) with low isotopic fractionation $(+0.5 \% \circ \pm 2.4 \%$, Nehlich 2015), especially when compared to the oxygen isotopic system. A recent study also measured very low sulphur isotope fractionation values between the collagen of sub-fossil red fox and that of its preys (ranging from -0.54 to $+0.03 \%$, with a mean analytical error of \pm 0.4 ; Krajcarz et al. 2019). Notably, this study further allows such low sulphur isotope fractionation to apply for carnivores.

Sulphur isotope analysis of vertebrate organic tissues is, therefore, particularly relevant to differentiate between freshwater and seawater environments. In particular, this method has been successfully used to determine the living environment exploited by 
fish at the species and population levels (Fry 2002; Fry and Chumchal 2011; Hesslein et al. 1991; Nehlich et al. 2013; Trembaczowski 2011) or in archaeological studies to know if ancient human populations relied on freshwater or marine food resources (e.g. Bocherens et al. 2016). More generally, terrestrial environments (including freshwater ones) and animals living there have generally relatively low $\delta^{34} \mathrm{~S}$ values compared to marine environments. Nonetheless, it is worth to note that coastal or island environments may be substantially influenced by sulphate from marine environments, which can be redeposited as rain or aerosols (the so-called 'sea spray' effect) with sulphate $\delta^{34} \mathrm{~S}$ values close to those of marine environment $(+20.3 \%$; Nielsen 1974; Norman et al. 2006). Consequently, the $\delta^{34} \mathrm{~S}$ values of vertebrates living in those terrestrial environments submitted to sea spray effect can be relatively high and may complicate interpretation concerning the living environment.

Due to technical difficulties, sulphur isotope analyses have been only applied to organic tissues that easily degrade after animal death and are rarely preserved in the fossil record. A new method has been recently developed to measure the sulphur isotope ratios $\left({ }^{34} \mathrm{~S}{ }^{\beta 2} \mathrm{~S}\right)$ of sulphate compound in calcium phosphate minerals (analytical precision equals $0.5 \%$ o $(1 \sigma)$ ) with a low-S concentration $(0.14 \%$ to $1.19 \%)$ such as vertebrate bioapatites (Fourel et al. 2015; Goedert et al. 2016). Previous results indicated that sulphur isotope compositions of environmental waters are recorded in vertebrate inorganic tissues (bone apatite) with low isotopic fractionation $(0.8 \% 0 \pm$ $0.8 \%, n=5$; Goedert et al. 2018). Therefore, sulphur isotope analysis of bioapatite from extinct vertebrates can provide estimates of the salinity of their aqueous environments (Goedert et al. 2018).

\section{Material and methods}

Sixty-four vertebrate bone apatite samples have been collected and analysed in this study (Online Information 1). Samples were selected to encompass a broad ecological and taxonomic spectrum of vertebrates (crocodiles, snakes, turtles, mammals, birds, lizards, fish and amphibians). For each taxonomic group, vertebrates of distinct ecology such as aquatic (freshwater vs marine), semi-aquatic and terrestrial were selected (Online Information 2). Oxygen and sulphur isotope analyses have been performed on each bone sample of the 64 vertebrates.

Forty vertebrate bone apatite samples were collected in the osteological collections of the 'Musée des Confluences' of Lyon, France. Samples were further selected in historical collections to ensure a wild provenance. Specimens with a labelled precise localisation were prioritised when possible. In addition, 24 vertebrate bone apatite samples for which sulphur isotope composition have been previously published (Goedert et al. 2016, 2018; cf. Table 1) have been added to the dataset and their oxygen isotope composition measured in this study. For each specimen, about $100 \mathrm{mg}$ of bone powder was sampled using a spherical diamond-tipped drill bit. The surface of the bone, which may have been chemically treated for curatorial purpose (samples coming from the 'Musée des Confluences'), was removed prior to sampling.

All statistical tests were performed using Past 3.22 software. We used Mann-Whitney $U$ test to compare the different median values and give the associated $P$ value $(P)$. Data of Figs. 1 and 2 were plotted using KaleidaGraph 4.5.3 software. Figures were drawn using Inkskape 0.92.3.

\section{Oxygen isotope analysis}

Bone apatite samples were treated following the wet chemistry protocol described by (Crowson et al. 1991) and slightly modified by (Lécuyer et al. 1993). This protocol consists in the isolation of phosphate $\left(\mathrm{PO}_{4}{ }^{3-}\right)$ from apatite using acid dissolution and anion-exchange resin. For each sample, $30 \mathrm{mg}$ of enamel powder was dissolved in $2 \mathrm{~mL}$ of $2 \mathrm{M}$ HF overnight. The $\mathrm{CaF}_{2}$ residue was separated by centrifugation, and the solution was neutralised by adding $2.2 \mathrm{~mL}$ of $2 \mathrm{M} \mathrm{KOH} .2 .5 \mathrm{~mL}$ of Amberlite ${ }^{\mathrm{TM}}$ anionexchange resin was added to the solution to separate the $\mathrm{PO}_{4}{ }^{3-}$ ions. After $24 \mathrm{~h}$, the solution was removed and the resin was eluted with $27.5 \mathrm{~mL}$ of $0.5 \mathrm{M} \mathrm{NH}_{4} \mathrm{NO}_{3}$. After $4 \mathrm{~h}, 0.5 \mathrm{~mL}$ of $\mathrm{NH}_{4} \mathrm{OH}$ and $15 \mathrm{~mL}$ of an ammoniacal solution of $\mathrm{AgNO}_{3}$ were added, and the samples were placed in a thermostated bath at $70{ }^{\circ} \mathrm{C}$ during $7 \mathrm{~h}$, allowing the precipitation of silver phosphate $\left(\mathrm{Ag}_{3} \mathrm{PO}_{4}\right)$ crystals. When only a few mg of apatite powders could be collected, the wet chemistry procedure was adapted following (Bernard et al. 2009) for small sample weights (about $3 \mathrm{mg}$ ).

Oxygen isotope compositions were measured using a high-temperature pyrolysis (Py) technique involving a VarioPYROcube ${ }^{\mathrm{TM}}$ elemental analyser (EA) interfaced in continuous flow (CF) mode to an Isoprime ${ }^{\mathrm{TM}}$ isotopic ratio mass spectrometer (IRMS) (EA-Py-CF-IRMS technique (Fourel et al. 2011; Lécuyer et al. 2007) at the Laboratoire de Géologie de Lyon (UMR 5276, Université Claude Bernard Lyon 1). For each sample, 5 aliquots of $300 \mu \mathrm{g}$ of $\mathrm{Ag}_{3} \mathrm{PO}_{4}$ were mixed with $300 \mu \mathrm{g}$ of pure graphite powder and loaded in silver foil capsules. Pyrolysis was performed at $1450{ }^{\circ} \mathrm{C}$. Measurements were calibrated against the NBS120c (natural Miocene phosphorite from Florida: $\delta^{18} \mathrm{O}=21.7 \%$ (V-SMOW), (Lécuyer et al. 1993) and the NBS127 (barium sulphate, $\mathrm{BaSO}_{4}: \delta^{18} \mathrm{O}=9.3 \%$ o (V-SMOW), (Hut 1987). Silver phosphate samples precipitated from standard NBS120c were repeatedly analysed $\left(\delta^{18} \mathrm{O}_{\mathrm{p}}=21.6 \%\right.$; $\left.1 \sigma=0.4 ; n=16\right)$ along with the silver phosphate samples derived from fossil bioapatites to ensure that no isotopic fractionation took place during the 

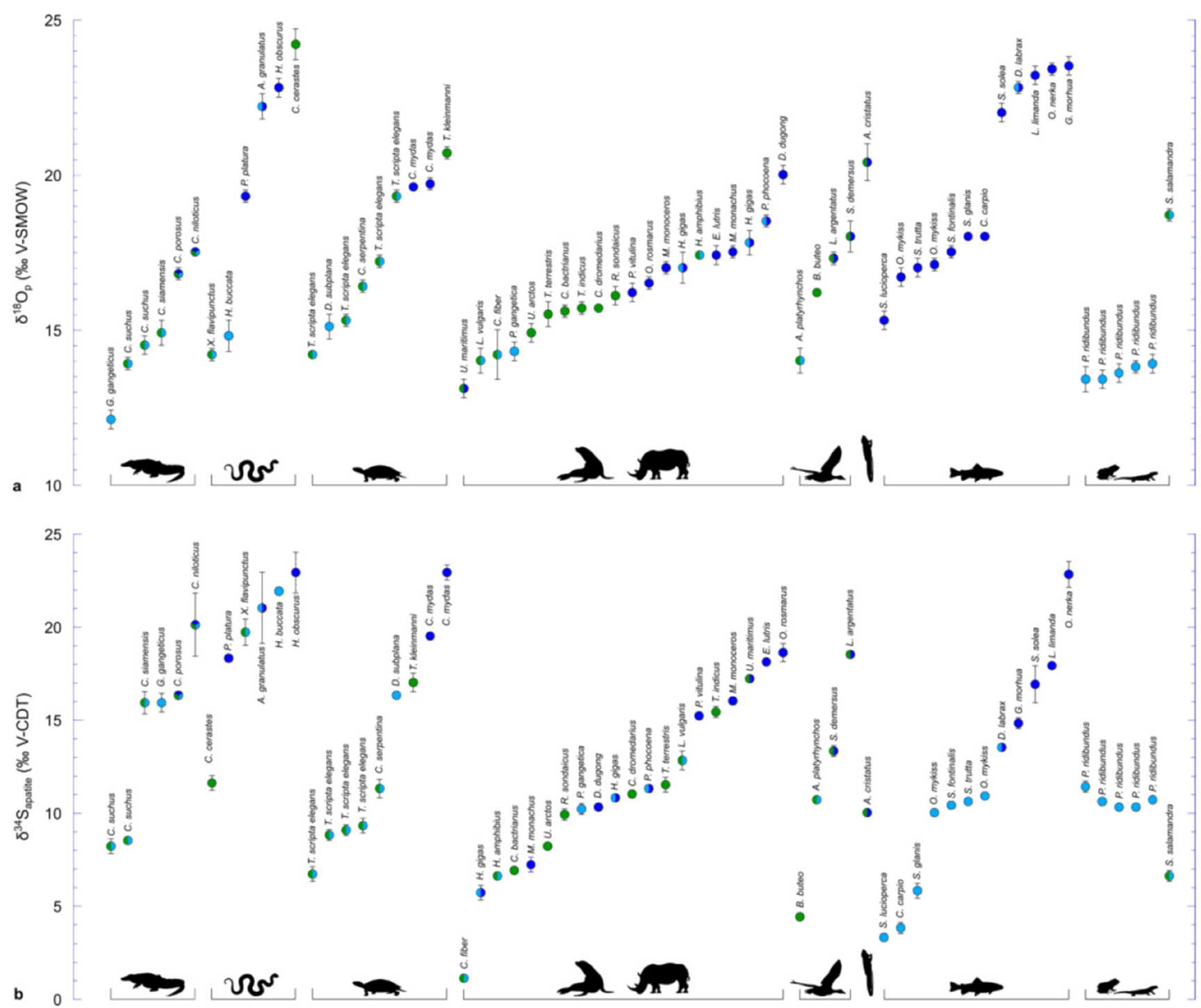

Fig. $1 \delta^{18} \mathrm{O}_{\mathrm{p}}$ and $\delta^{34} \mathrm{~S}_{\text {apatite }}$ values of modern vertebrates including (from left to right) crocodiles, snakes, turtles, mammals, birds, lizards, fish and amphibians. a Oxygen isotope composition of bone phosphate $\left(\delta^{18} \mathrm{O}_{\mathrm{p}}\right)$ as variations in parts per mille from the ratio of ${ }^{18} \mathrm{O} /{ }^{16} \mathrm{O}$ in Vienna Mean Ocean Water (\% VSMOW) b Sulphur isotope composition of bone apatite $\left(\delta^{34} \mathrm{~S}_{\text {apatite }}\right)$ as variations in parts per mille from the ratio of ${ }^{34} \mathrm{~S}{ }^{32} \mathrm{~S}$ in Vienna Canyon Diablo Troilite (\%o VCDT). For a, b, each data point represents a biologically independent animal $(n=64)$ and wet chemistry. The NBS120c average standard deviation equals $0.29 \pm 0.14 \%$ o. Data are reported as $\delta^{18} \mathrm{O}_{\mathrm{p}}$ in $\%$ o values vs V-SMOW.

\section{Sulphur isotope analysis}

Sulphur isotope compositions were measured using a VarioPYROcube ${ }^{\mathrm{TM}}$ elemental analyser in NCS combustion mode interfaced in continuous-flow mode with an Isoprime $100^{\mathrm{TM}}$ isotope ratio mass spectrometer hosted by the platform 'Ecologie Isotopique' of the 'Laboratoire d'Ecologie des Hydrosystèmes Naturels et Anthropisés' (LEHNA, corresponds to the average value of five and three repeated measurements for oxygen and sulphur isotope analysis, respectively (see "Material and Methods"). Each error bar corresponds to 1 s.d. (Online Information 1). For both panels, light blue, dark blue and green colours indicate that the species lives in freshwater, seawater or terrestrial environments, respectively (see Supplementary Information). The name of each species is indicated close to the corresponding dot

UMR 5023, Villeurbanne, France). For each bone apatite sample, 3 aliquots of $7 \mathrm{mg}$ of bioapatite powder were mixed with $20 \mathrm{mg}$ of pure tungsten oxide $\left(\mathrm{WO}_{3}\right)$ powder and loaded in tin foil capsules. Tungsten oxide is a powerful oxidant ensuring the full thermal decomposition of apatite sulphate into sulphur dioxide $\left(\mathrm{SO}_{2}\right)$ gas (Goedert et al. 2016). Measurements have been calibrated against the NBS127 (barium sulphate, $\mathrm{BaSO}_{4} \delta^{34} \mathrm{~S}=+20.3 \%$ (VCDT), (Halas and Szaran 2001) and S1 (silver sulphide, $\mathrm{Ag}_{2} \mathrm{~S} \delta^{34} \mathrm{~S}=-0.3 \%$ o (V-CDT), (Robinson 1995) international standards. For each analytical run of bone samples, we have also analysed BCR32 samples as a compositional 


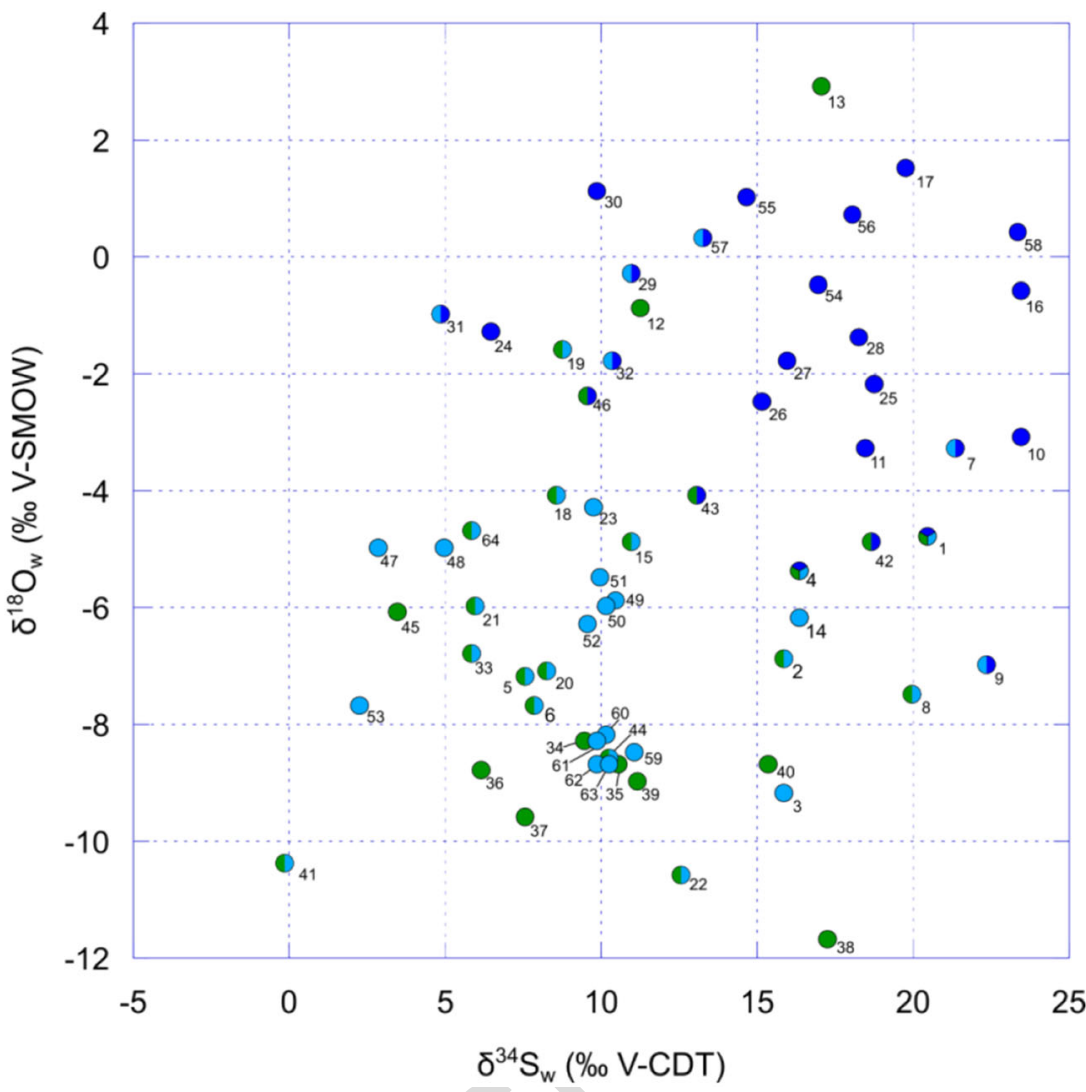

Fig. 2 Reconstructed oxygen and sulphur isotope composition of the environmental waters $\left(\delta^{18} \mathrm{O}_{\mathrm{w}}, \delta^{34} \mathrm{~S}_{\mathrm{w}}\right)$ of the modern vertebrates. For oxygen, the isotopic composition of water was calculated using published isotopic fractionation equations for different groups of vertebrates (Online Information 3). For sulphur, the isotopic composition of water is very close to that recorded in bone apatite (i.e., almost no isotopic fractionation) and was calculated using published values of sulphur isotope composition of bone apatite and associated environmental water measured in present-day vertebrates (Goedert et al. (2018); Online Information 4). Each data point represents a biologically independent animal $(n=64)$ and corresponds to the average value of five and three repeated measurements for oxygen and sulphur isotope analysis, respectively (see "Material and Methods"). Each dot is numbered according to the species it represents (cf. Table 1). Error bars of each individual data point are given in Table S2 and S3 for oxygen and sulphur respectively. Results are given as variations in parts per mille from the ratio of ${ }^{18} \mathrm{O} /{ }^{16} \mathrm{O}$ in Vienna Mean Oean Water (\%o VSMOW) for oxygen and ${ }^{34} \mathrm{~S} /{ }^{32} \mathrm{~S}$ in Vienna Canyon Diablo Troilite (\%o VCDT) for sulphur. Species living in freshwater are represented by light blue dots; those living in seawater are represented by dark blue dots, and green dots are used for terrestrial species.(1): Crocodylus niloticus; (2): Crocodylus siamensis; (3): Gavialis gangeticus; (4): Crocodylus porosus; (5): Crocodylus suchus; (6): Crocodylus suchus; (7): Acrochordus

and isotopic standard $(\mathrm{S} \%=0.72$, certified value ((Community Bureau of Reference 1982); $\delta^{34} \mathrm{~S}=18.4 \%$ o (V-CDT), (Fourel et al. 2015; Goedert et al. 2016) to ensure that analytical conditions were optimal to perform sulphur isotope analyses of samples with low-S content. The sample average standard deviation for $\delta^{34} \mathrm{~S}$ measurements is $0.34 \%$ o $\pm 0.34 \%$. Data are reported as $\delta^{34} \mathrm{~S}$ in \%o vs V-CDT. granulatus; (8): Xenochrophis flavipunctus; (9): Homalopsis buccata; (10): Hydrophis obscurus; (11): Pelamis platura; (12): Cerastes cerastes; (13): Testudo kleinmanni; (14): Dogania subplana; (15): Chelydra serpentina; (16): Chelonia mydas; (17): Chelonia mydas; (18): Trachemys scripta elegans; (19): Trachemys scripta elegans; (20): Trachemys scripta elegans; (21): Trachemys scripta elegans; (22): Lutra lutra; (23): Platanista gangetica; (24): Monachus monachus; (25): Odobenus rosmarus; (26): Phoca vitulina; (27): Monodon monoceros; (28): Enhydra lutris; (29): Phocoena phocoena; (30): Dugong dugon; (31): Hydrodamalis gigas; (32): Hydrodamalis gigas; (33): Hippopotamus amphibius; (34): Rhinoceros sondaicus; (35): Camelus dromedarius; (36): Camelus bactrianus; (37): Ursus arctos; (38): Ursus maritimus; (39): Tapirus indicus; (40): Tapirus terrestris; (41): Castor fibre; (42): Larus argentatus; (43): Spheniscus demersus; (44): Anas platyrhynchos; (45): Buteo buteo; (46): Amblyrhynchus cristatus; (47): Cyprinus carpio; (48): Silurus glanis; (49): Oncorhynchus mykiss; (50): Salmo trutta; (51): Salvelinus fontinalis; (52): Oncorhynchus mykiss; (53): Sander lucioperca; (54): Solea solea; (55): Gadus morhua; (56): Limanda limanda; (57): Dicentrarchus labrax; (58): Oncorhynchus nerka; (59): Pelophylax ridibundus; (60): Pelophylax ridibundus; (61): Pelophylax ridibundus; (62): Pelophylax ridibundus; (63): Pelophylax ridibundus; (64): Salamandra salamandra

\section{Results}

\section{Oxygen isotope}

The different vertebrates analysed had oxygen isotope compositions ranging from +12.1 to $+24.2 \%$ o -SMOW (Online Information 1; Fig. 1a), which mainly reflect the variability of oxygen isotope compositions of environmental waters. On the 
whole, vertebrates living or foraging in marine environments had significantly higher $\delta^{18} \mathrm{O}_{\mathrm{p}}$ values than animals living or foraging in continental (freshwater or terrestrial) environments (median $\delta^{18} \mathrm{O}_{\mathrm{p}}=+19.8 \%$ o, $1 \sigma=3.0, n=18$ vs median $\delta^{18} \mathrm{O}=+15.4 \% o, 1 \sigma=2.4, n=40 ; P=4.244 \mathrm{e}-5$ (MannWhitney $U$ test)). It also worth to note that vertebrates which live in both freshwater to seawater environment had intermediate median $\delta^{18} \mathrm{O}_{\mathrm{p}}$ values $\left(\delta^{18} \mathrm{O}_{\mathrm{p}}=+17.7 \%\right.$ o, $\left.1 \sigma=0.9, n=6\right)$, although the difference was only significant compared to continental environments and not seawater ones $(P=0.01255$ and $P=0.1611$, respectively). One exception concerns the horned desert viper (Cerastes cerastes) and the Kleinmann's tortoise (Testudo kleinmanni), which had both recorded high oxygen isotope ratios in their bones due to their desert lifestyle.

\section{Sulphur isotope}

The different vertebrates analysed had sulphur isotope compositions apatite $\left(\delta^{34} \mathrm{~S}_{\text {apatite }}\right)$ ranging from +1.1 to $+22.9 \%$ VCDT (Online Information 1; Fig. 1b). On the whole, vertebrates living or foraging in marine environments had significantly higher $\delta^{34} \mathrm{~S}$ values than those living or foraging in continental (freshwater or terrestrial) environments (median $\delta^{34} \mathrm{~S}_{\text {apatite }}=+16.9 \%, 1 \sigma=4.4, n=18$ vs $\delta^{34} \mathrm{~S}_{\text {apatite }}=+$ $10.4 \% o, 1 \sigma=4.4, n=40 ; P=0.0001357)$. This isotopic pattern reflects an almost systematic ${ }^{34} \mathrm{~S}$-enrichment of marine environments compared to continental ones. It is again worth to note that vertebrates living in freshwater to seawater environment had intermediate median $\delta^{34} \mathrm{~S}_{\text {apatite }}$ values $\left(\delta^{34} \mathrm{~S}=+\right.$ $13.8 \%, 1 \sigma=6.0, n=6)$, although the difference was not significant with that of continental or marine environments $(P=$ 0.1063 and $P=0.5264)$. Sulphur isotope analysis of fossilised apatite can, therefore, help to detect the presence or proximity of seawater in the living environments of extinct vertebrates.

\section{Discussion}

\section{Oxygen isotope composition}

Oxygen isotope analysis of vertebrate biogenic apatite has been widely applied to fossilised apatite of extinct vertebrates to get information on their living environment (e.g. Clementz et al. 2003, 2006; Tütken et al. 2006; Amiot et al. 2015, 2009, 2010; Pouech et al. 2014; Guy et al. 2018). As illustrated by our results, this analysis can be particularly useful to distinguish vertebrates living or foraging in marine environments from those living or foraging in continental (freshwater or terrestrial) ones (e.g. sharks: Gates 2019; mosasaurs: Makádi et al. 2012; coelacanths: Simon et al. 2003).

It can also be used to further differentiate aquatic or semiaquatic lifestyle from a terrestrial one in the case of sympatric vertebrates (e.g. Amiot et al. 2010). Indeed, terrestrial animals lose more water than semi-aquatic animals through transcutaneous evaporation or sweat. Water lost during this process as vapour is preferentially ${ }^{16} \mathrm{O}$-enriched, resulting in a relative ${ }^{18} \mathrm{O}$-enrichment of the residual body water (Cerling et al. 2008). Although the different vertebrates sampled come from different region of the world, it should be noted for instance that the Eurasian otter (Lutra lutra) and the Eurasian beaver (Castor fibre), both having a semi-aquatic lifestyle, have recorded lower oxygen isotope ratios in their bones than fully terrestrial mammals (Online Information 1 and Fig. 1a). This is also the case for the semi-aquatic mallard duck (Anas platyrhynchos), which recorded in its bones lower oxygen isotope ratios than the common buzzard (Buteo buteo) (Online Information 1 and Fig. 1). In the latter case, it is worthy to note that both specimens come from the same geographic area and therefore rely on environmental waters of comparable oxygen isotope compositions.

On the contrary, it can be used to detect desert lifestyle (Lécuyer et al. 1999). For instance, the horned desert viper (Cerastes cerastes) and the Kleinmann's tortoise (Testudo kleinmanni), had both recorded high oxygen isotope ratios in their bones.

Nonetheless, for low-latitude environments, oxygen isotope compositions of freshwater and marine environments can display significant overlap. Consequently, water oxygen isotope compositions recorded in vertebrate apatites may not always be a diagnostic tracer of their living environment (e.g. Pouech et al. 2014).

\section{Sulphur isotope composition}

Compared to oxygen, sulphur isotopes have been less applied to question the ecology of extinct vertebrates, principally due to technical difficulties. Due to the large amplitude of natural isotopic variations, particularly observed between terrestrial and marine environments, it remains a particularly relevant environmental tracer (cf. Background information).

However, as discussed in the "Introduction" section, the 'sea spray' effect may complicate interpretation concerning the living environment of vertebrates for terrestrial environment located in the influenced of marine ones. Moreover, some freshwater settings may have sulphur isotope compositions close to that of marine environments. For instance, rivers draining basins in which marine evaporites are exposed may have elevated dissolved sulphate content (more than $200 \mathrm{mg} / \mathrm{L}$ for the Colorado River system (Shope and Gerner 2014)) and $\delta^{34} \mathrm{~S}$ values (up to seawater-like $19.5 \%$ for the Mackenzie River system (Hitchon and Krouse 1972)). Therefore, vertebrates living in such environments are expected to have high sulphur isotope compositions that could be misinterpreted as reflecting an aqueous environment at least submitted to some marine influences. Finally, vertebrate species living in aquatic environments submitted to the influences of both fresh and 
marine water, like in estuaries, may record a sulphur isotope composition in their bioapatite difficult to correctly interpret in terms of living environment.

\section{Combined oxygen and sulphur isotope composition}

On the whole, the combined use of oxygen and sulphur isotope compositions of bone apatite allows, in most cases, environmental identification for the present-day vertebrates after the conversion of the measured $\delta^{18} \mathrm{O}$ and $\delta^{34} \mathrm{~S}$ values of apatite into environmental water $\delta^{18} \mathrm{O}$ value and dissolved environmental sulphate $\delta^{34} \mathrm{~S}$ values using known isotopic fractionation equations (Fig. 2; Online Information 3 and 4).

The complementarity of these two isotopic systems lies in the different abundance ratios of oxygen and sulphur, respectively, in seawater and freshwater bodies. Indeed, oxygen is equally present $\left(\right.$ as $\left.\mathrm{H}_{2} \mathrm{O}\right)$ in both marine and freshwater reservoirs whereas sulphur content (as $\mathrm{SO}_{4}{ }^{2-}$ ) of seawater is generally 100 to 1000 higher than in freshwater (Fry and Chumchal 2011). Consequently, sulphur isotopes will be particularly relevant to detect the presence of seawater in the environment, even if only a small quantity of seawater intrudes freshwater environment, and oxygen isotopes will be relevant to quantify the amount of freshwater in the environment, in particular in aquatic environments where freshwater and seawater are mixing, like in deltas or estuaries (Goedert et al. 2018).

Vertebrates living or foraging in marine environments tend to have higher oxygen and sulphur isotope compositions recorded in their bone apatite than those from freshwater and terrestrial habitats. This rule is especially valid when we compare vertebrates of close phylogenetic affinity. For instance, the wild gharial (Gavialis gangeticus), living in freshwater streams, and the two captive specimens of desert crocodiles (Crocodylus suchus), kept in freshwater at the Zoo of Lyon, have recorded in their bone apatite $\delta^{18} \mathrm{O}_{\mathrm{p}}$ and $\delta^{34} \mathrm{~S}_{\text {apatite }}$ values $(+12.1 \%$ and $+15.9 \%$, + $14.5 \%$ and $+8.2 \%$, and $+13.9 \%$ and $+8.5 \%$, respectively) lower than those measured in bones of the wild Nile crocodile (Crocodilus niloticus; $+17.5 \%$ and $+20.1 \%$ ) and saltwater crocodile (Crocodilus porosus; $+16.8 \%$ and $+16.3 \%$ ), both known to undertake incursions in brackish waters to seawaters (cf. Supplementary Information). Similarly, the sea otter (Enhydra lutris), fully adapted to life in seawater, has higher $\delta^{18} \mathrm{O}_{\mathrm{p}}$ and $\delta^{34} \mathrm{~S}_{\text {apatite }}$ values $(+17.4 \%$ and $+18.1 \%$ ) than those of the Eurasian otter (Lutra lutra) $\left(\delta^{18} \mathrm{O}_{\mathrm{p}}=+14.0 \%\right.$ and $\delta^{34} \mathrm{~S}=+12.8 \%$ ), inhabiting freshwater environments. In a similar way, the marine narwhal (Monodon monoceros) has higher $\delta^{18} \mathrm{O}_{\mathrm{p}}$ and $\delta^{34} \mathrm{~S}_{\text {apatite }}$ values $(+17.0 \%$ and $+16.0 \%$ ) than those of the South Asian river dolphin (Platanista gangetica; $+14.3 \%$ o and $+10.2 \%$ ) .

The general picture we have of major ecological transitions that took place during vertebrate evolution are incomplete and potentially biased as it corresponds to the final stages of these transitions. For instance, the colonisation of terrestrial environments by early tetrapods at the beginning of the Carboniferous gave rise to a wide evolutionary radiation of terrestrial tetrapods that are still present on lands today. Similarly, the multiple iterations of secondary adaptation to the aquatic environment are well illustrated by the numerous species of vertebrates belonging to different groups (crocodiles, snakes, turtles, lizards, birds and mammals), which live in present-day aquatic environments. All these vertebrates testify that different groups adapted to new environments from a common ancestor. However, the way these major ecological transitions proceeded, especially during their early stages, is difficult to infer and often remained elusive. Indeed, morpho-functional adaptations to a specific environment can be diachronous with its effective use (exaptation); the diagnose of living environment of vertebrates from morpho-functional analysis is thereby limited. Therefore, the combined use of ${ }^{18} \mathrm{O} /{ }^{16} \mathrm{O}$ and ${ }^{34} \mathrm{~S} /{ }^{\beta 2} \mathrm{~S}$ ratios of skeletal apatite should be particularly promising and powerful to document major ecological transitions in the fossil record for any phylogenetic group of vertebrates. For instance, this method has already been successfully applied to determine the aquatic environment of some Devonian early tetrapods and their associated vertebrate fauna (Goedert et al. 2018). Furthermore, it could also help to precise the ecology of some present-day aquatic vertebrates and shed light on the modalities of transition between terrestrial and aquatic environments during the course of vertebrate evolution over the Phanerozoic. It is also worthy to note that this method has the potential to shed light on the ecology of numerous present-day vertebrates living in transitional environments, and for which the ecology remains unclear.

Acknowledgements We thank the Musée des Confluences de Lyon, M. Creuzé des Châtelliers (Centre de Ressources pour les Sciences de l'Evolution (CERESE, FED 4271, Université de Lyon, Université Claude Bernard Lyon 1)), G. Douay (Zoo de Lyon), O. de Lataillade (Ferme du Ciron), P. François (Pierrelatte), E. Liatout (Maison Liatout) and the fishery (Maison Pupier) for providing bone material. Sulphur and oxygen isotope compositions were measured at the platforms 'Ecologie Isotopique' (LEHNA) 'Isotopes Stables' (LGLTPE), respectively.

Author contribution statement All authors contributed to the study conception and design. Material preparation and data collection were performed by J. Goedert, D. Berthet and R. Amiot. Material analysis were performed by J. Goedert, F. Fourel and L. Simon. The first draft of the manuscript was written by J. Goedert, R. Amiot and C. Lécuyer, and all authors commented on previous versions of the manuscript. All authors read and approved the final manuscript.

Funding information This study was supported by the CNRS INSU program InterrVie, and the Institut Universitaire de France (C.L.).

Data availability All data generated or analysed during this study are included in this published article [and its online information files].

\section{Compliance with ethical standards}

Conflict of interest The authors declare that they have no conflict of interest. 


\section{Q7478 References}

479

480

481

482

483

484

485

486

487

488

489

490

491

492

493

494

495

496

497

498

499

500

501

502

503

504

505

506

507

508

509

510

511

512

513

514

515

516

517

518

519

520

521

522

523

524

525

526

527

528

529

530

531

532

533

534

535

536

537

538

539

540

541
Ahlberg PE, Milner AR (1994) The origin and early diversification of tetrapods. Nature 368:507

Amiot R, Buffetaut E, Lécuyer C et al (2009) Oxygen isotope composition of continental vertebrate apatites from Mesozoic formations of Thailand; environmental and ecological significance. Geol Soc Lond, Spec Publ 315:271-283

Amiot R, Buffetaut E, Lécuyer C et al (2010) Oxygen isotope evidence for semi-aquatic habits among spinosaurid theropods. Geology 38:139-142

Amiot R, Wang X, Zhou Z et al (2015) Environment and ecology of East Asian dinosaurs during the Early Cretaceous inferred from stable oxygen and carbon isotopes in apatite. J Asian Earth Sci 98:358-370

Bernard A, Daux V, Lécuyer C et al (2009) Pleistocene seasonal temperature variations recorded in the $\delta 18 \mathrm{O}$ of Bison priscus teeth. Earth Planet Sci Lett 283:133-143

Bocherens H, Drucker DG, Haidle MN et al (2016) Isotopic evidence (C, $\mathrm{N}, \mathrm{S}$ ) for a high aquatic dietary contribution for a Pre-Dorset muskox hunter from Umingmak (Banks Island, Canada). J Archaeol Sci Rep 6:700-708

Böttcher ME, Brumsack H-J, Dürselen C-D (2007) The isotopic composition of modern seawater sulfate: I. Coastal waters with special regard to the North Sea. J Mar Syst 67:73-82. https://doi.org/10. 1016/j.jmarsys.2006.09.006

Cerling TE, Harris JM, Hart JA et al (2008) Stable isotope ecology of the common hippopotamus. J Zool 276:204-212

Clementz MT, Hoppe KA, Koch PL (2003) A paleoecological paradox: the habitat and dietary preferences of the extinct tethythere Desmostylus, inferred from stable isotope analysis. Paleobiology 29:506-519

Clementz MT, Goswami A, Gingerich PD, Koch PL (2006) Isotopic records from early whales and sea cows: contrasting patterns of ecological transition. J Vertebr Palaeontol 26:355-370

Coates MI, Clack JA (1990) Polydactyly in the earliest known tetrapod limbs. Nature 347:66-69. https://doi.org/10.1038/347066a0

Community Bureau of Reference (1982) Certified reference material certificate of analyses for BCR No. 32. Commission of the European Communities, Report No. 541

Craig H, Gordon LI (1965) Deuterium and oxygen 18 variations in the ocean and the marine atmosphere. In: Tongiorgo E, Spoleto CNR (eds) Stable Isotopes in Oceanographic Studies and Paleotemperatures. Lab. of Nuclear Geology, Pisa

Crowson RA, Showers WJ, Wright EK, Hoering TC (1991) Preparation of phosphate samples for oxygen isotope analysis. Anal Chem 63: 2397-2400

Dansgaard W (1964) Stable isotopes in precipitation. Tellus 16:436-468

Fernández M, Gasparini Z (2000) Salt glands in a Tithonian metriorhynchid crocodyliform and their physiological significance. Lethaia 33:269-276

Fourel F, Martineau F, Lécuyer C et al (2011) 18O/16O ratio measurements of inorganic and organic materials by elemental analysispyrolysis-isotope ratio mass spectrometry continuous-flow techniques. Rapid Commun Mass Spectrom 25:2691-2696

Fourel F, Martineau F, Seris M, Lécuyer C (2015) Measurement of 34S/ 32S Ratios of NBS 120c and BCR 32 Phosphorites Using Purge and Trap EA-IRMS Technology. Geostand Geoanal Res 39:47-53. https://doi.org/10.1111/j.1751-908X.2014.00297.x

Fry B (2002) Stable isotopic indicators of habitat use by Mississippi River fish. J N Am Benthol Soc 21:676-685

Fry B, Chumchal MM (2011) Sulphur stable isotope indicators of residency in estuarine fish. Limnol Oceanogr 56:1563-1576

Gat JR (1984) The stable isotope composition of dead sea waters. Earth Planet Sci Lett 71:361-376

Gat JR, Levy Y (1978) Isotope hydrology of inland sabkhas in the Bardawil area, Sinai. Limnol Oceanogr 23:841-850
Gat JR, Shemesh A, Tziperman E et al (1996) The stable isotope composition of waters of the eastern Mediterranean Sea. J Geophys Res Oceans 101:6441-6451

Gates TA, Gorscak E, Makovicky PJ (2019) New sharks and other chondrichthyans from the latest Maastrichtian (Late Cretaceous) of North America. J Palaeontol 93:512-530

Gingerich PD, ul Haq M, Zalmout IS et al (2001) Origin of whales from early artiodactyls: hands and feet of Eocene Protocetidae from Pakistan. Science 293:2239-2242

Goedert J, Fourel F, Amiot R et al (2016) High-precision 34S/32S measurements in vertebrate bioapatites using purge-and-trap EA-IRMS technology. Rapid Commun Mass Spectrom

Goedert J, Lécuyer C, Amiot R et al (2018) Euryhaline ecology of early tetrapods revealed by stable isotopes. Nature 558:68-72

Guy S-V, Thomas T, Irit Z et al (2018) Tooth oxygen isotopes reveal Late Bronze Age origin of Mediterranean fish aquaculture and trade. Sci Rep 8:1-10. https://doi.org/10.1038/s41598-018-32468-1

Halas S, Szaran J (2001) Improved thermal decomposition of sulfates to SO2 and mass spectrometric determination of 834 S of IAEA SO-5, IAEA SO-6 and NBS-127 sulfate standards. Rapid Commun Mass Spectrom 15:1618-1620. https://doi.org/10.1002/rcm.416

Hesslein RH, Capel MJ, Fox DE, Hallard KA (1991) Stable isotopes of sulphur, carbon, and nitrogen as indicators of trophic level and fish migration in the lower Mackenzie River basin, Canada. Can J Fish Aquat Sci 48:2258-2265

Hitchon B, Krouse HR (1972) Hydrogeochemistry of the surface waters of the Mackenzie River drainage basin, Canada - III. Stable isotopes of oxygen, carbon and sulphur. Geochim Cosmochim Acta 36: 1337-1357. https://doi.org/10.1016/0016-7037(72)90066-X

Hut G (1987) Stable isotope reference samples for geochemical and hydrological investigations. Consultant Group Meeting IAEA, Vienna, 16-18 September 1985, Report to the Director General. International Atomic Energy Agency, Vienna 42

Kaplan IR (1983) Stable isotopes of sulphur, nitrogen and deuterium in recent marine environments. In: Arthur MA, Anderson TF, Kaplan IR, Veizer J, Land LS (eds) Stable isotopes in sedimentary geology. Society of Sedimentary Geology, pp 2.1-2.108

Kohn MJ (1996) Predicting animal $\delta 180$ : accounting for diet and physiological adaptation. Geochim Cosmochim Acta 60:4811-4829

Krajcarz MT, Krajcarz M, Drucker DG, Bocherens H (2019) Prey-to-fox isotopic enrichment of $34 \mathrm{~S}$ in bone collagen: implications for palaeoecological studies. Rapid Commun Mass Spectrom

Krouse H (1980) Sulphur isotopes in our environment. In: Handbook of Environmental Isotope Geochemistry, Fritz and Fontes. pp. 435-472.

Lécuyer C, Grandjean P, O'Neil JR et al (1993) Thermal excursions in the ocean at the Cretaceous - Tertiary boundary (northern Morocco): $\delta 180$ record of phosphatic fish debris. Palaeogeogr Palaeoclimatol Palaeoecol 105:235-243

Lécuyer C, Grandjean P, Mazin J-M, De Buffrénil V (1999) Oxygen isotope compositions of reptile bones and teeth: a potential record of terrestrial and marine paleoenvironments. In: Hoch E (ed) Secondary Adaptation to Life in Water II, Geologisk Museum, University of Copenhagen. Brantsen, A.K., Denmark, p 33

Lécuyer C, Fourel F, Martineau F et al (2007) High-precision determination of $18 \mathrm{O} / 16 \mathrm{O}$ ratios of silver phosphate by EA-pyrolysis-IRMS continuous flow technique. J Mass Spectrom 42:36-41

Levin NE, Cerling TE, Passey BH et al (2006) A stable isotope aridity index for terrestrial environments. PNAS 103:11201-11,205. https://doi.org/10.1073/pnas.0604719103

Longinelli A (1984) Oxygen isotopes in mammal bone phosphate: a new tool for paleohydrological and paleoclimatological research? Geochim Cosmochim Acta 48:385-390. https://doi.org/10.1016/ 0016-7037(84)90259-X

Luz B, Kolodny Y, Kovach J (1984) Oxygen isotope variations in phosphate of biogenic apatites, III. Conodonts. Earth Planet Sci Lett 69:255-262 
607

608

609

610

611

612

613

614

615

616

617

618

619

620

621

622

623

624

625

626

627

628

629

630

631

654
Makádi L, Caldwell MW, Ösi A (2012) The first freshwater mosasauroid (Upper Cretaceous, Hungary) and a new clade of basal mosasauroids. PLoS One 7:1-16

Martin JE, Amiot R, Lécuyer C, Benton MJ (2014) Sea surface temperature contributes to marine crocodylomorph evolution. Nat Commun 5:4658

Martin JE, Deesri U, Liard R et al (2016) Strontium isotopes and the longterm residency of thalattosuchians in the freshwater environment. Paleobiology 42:143-156

Nehlich O (2015) The application of sulphur isotope analyses in archaeological research: a review. Earth Sci Rev 142:1-17. https://doi.org/ 10.1016/j.earscirev.2014.12.002

Nehlich O, Barrett JH, Richards MP (2013) Spatial variability in sulphur isotope values of archaeological and modern cod (Gadus morhua). Rapid Commun Mass Spectrom 27:2255-2262

Pierce SE, Clack JA, Hutchinson JR (2012) Three-dimensional limb joint mobility in the early tetrapod Ichthyostega. Nature 486:523

Pouech J, Amiot R, Lécuyer C et al (2014) Oxygen isotope composition of vertebrate phosphates from Cherves-de-Cognac (Berriasian, France): environmental and ecological significance. Palaeogeogr Palaeoclimatol Palaeoecol 410:290-299

Robinson BW (1995) Variations in the sulphur isotope composition of CDT. In: Reference and intercomparison materials for stable isotopes of light elements, Proceedings of a consultants meeting held in Vienna, 1-3. Dec. 1993. IAEA, Vienna, Austria, pp 39-45
Roe LJ, Thewissen JGM, Quade J et al (1998) Isotopic approaches to understanding the Terrestrial-to-Marine transition of the Earliest Cetaceans. In: The Emergence of Whales. Springer, Boston, pp 399-422

Shope CL, Gerner SJ (2014) Assessment of dissolved-solids loading to the Colorado River in the Paradox Basin between the Dolores River and Gypsum Canyon. US Geological Survey, Utah

Simon T, Hagdorn H, Hagdorn MK, Seilacher A (2003) Swimming trace of a coelacanth fish from the Lower Keuper of south-west Germany. Palaeontology 46:911-926

Spoor F, Bajpai S, Hussain ST et al (2002) Vestibular evidence for the evolution of aquatic behaviour in early cetaceans. Nature 417:163166. https://doi.org/10.1038/417163a

Trembaczowski A (2011) Use of sulphur and carbon stable-isotope composition of fish scales and muscles to identify the origin of fish. Mineralogia 42:33

Tütken T, Vennemann TW, Janz H, Heizmann EPJ (2006) Palaeoenvironment and palaeoclimate of the Middle Miocene lake in the Steinheim basin, SW Germany: a reconstruction from C, O, and $\mathrm{Sr}$ isotopes of fossil remains. Palaeogeogr Palaeoclimatol Palaeoecol 241:457-491

Publisher's note Springer Nature remains neutral with regard to jurisdictional claims in published maps and institutional affiliations. 